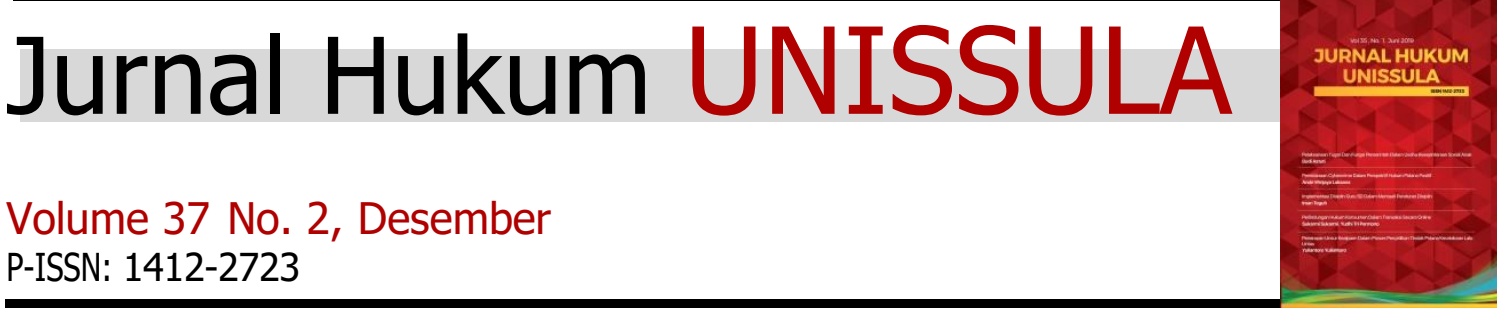

\section{PERSPECTIVE OF INTERNATIONAL LAW ON MARITIME TERRITORIAL DISPUTE: CASE BETWEEN KENYA AND SOMALIA}

\section{Yordan Gunawan}

Faculty of Law, Universitas Muhammadiyah Yogyakarta, E-mail:yordangunawan@umy.ac.id

Andi Agus salim

Faculty of Law, Universitas Muhammadiyah Yogyakarta, E-mail: andi.agus@umy.ac.id

Ewaldo Asirwadana

Faculty of Law, Universitas Muhammadiyah Yogyakarta, E-mail: ewaldo.a.law19@mail.umy.ac.id

\section{Satya Bayu Prasetyo}

Faculty of Law, Universitas Muhammadiyah Yogyakarta, E-mail: satya.bayu.law19@mail.umy.ac.id

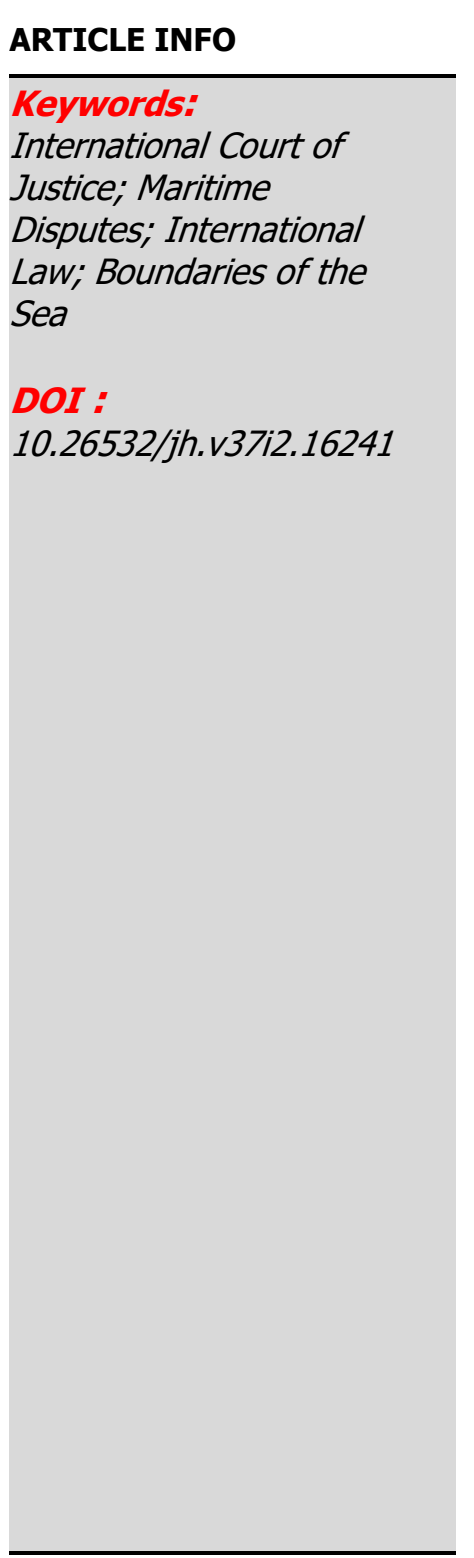

\begin{abstract}
Penelitian ini menganalisis sengketa maritim antara Kenya dan Somalia dalam perspektif hukum internasional. Kedua negara telah mengalami sengketa maritim atas batas laut lebih dari $100.000 \mathrm{~km}$ persegi dasar laut di perairan Samudera Hindia. Mereka mulai bersengketa setelah Somalia menuduh Kenya secara ilegal memberikan hak eksplorasi sumber daya di perairan kepada perusahaan multinasional, Total dan Eni. Seperti yang telah dinyatakan oleh Kenya, menyatakan perairan di lepas Pantai Afrika Timur adalah salah satu prospek eksplorasi minyak terpanas di dunia dan daerah yang diperebutkan memiliki cadangan hidrokarbon. Metode penelitian yang digunakan adalah penelitian hukum normatif. Sedangkan sifat penelitian ini adalah deskriptifkualitatif dengan teknik pengumpulan data dengan melakukan studi kepustakaan. Hasil penelitian menunjukkan bahwa sengketa batas laut telah memperburuk hubungan diplomatik antara Kenya dan Somalia yang sebenarnya harus dihindari oleh kedua negara. Sebelum membawa kasus ini ke Mahkamah Internasional (ICJ), kedua negara sepakat untuk menyelesaikan sengketa melalui negosiasi bilateral, namun kasus tersebut masih belum terselesaikan. Oleh karena itu, Somalia memutuskan untuk membawa kasus ini ke Pengadilan.
\end{abstract}

The research analysed the maritime dispute between Kenya and Somalia under the international law perspective. Both states have been experiencing maritime disputes over maritime boundaries of more than 100,000 sq $\mathrm{km}$ of seabed in the waters of the Indian Ocean. They began to clash after Somalia accusing Kenya of illegally granting exploration rights to resources in the waters to multinational companies, Total and Eni. As Kenya declared, the waters of the East African coast are one of the hottest oil exploration prospects in the world, and the contested area has hydrocarbon reserves. The research method is normative legal research. Accordingly, the nature of the research was descriptivequalitative with data collection techniques by conducting a literature study. The research shows that maritime boundary dispute has worsened diplomatic relations between Kenya and Somalia. Prior to bringing the case to the International Court of 


\section{A. INTRODUCTION}

The dispute that involves two countries on the African Continent is initiated by maritime border disputes. Both Kenya and Somalia have mutual claims to the territorial waters of the Indian Ocean. This dispute between Kenya and Somalia dates back many years. The disputed area is known to be rich in oil, given the importance of oil and gas to the economy of the country. Kenya and Somalia have tried to resolve their border dispute through negotiations, but to no avail, so the Somalia agency took action at the International Court of Justice (ICJ).

The disputed area is also the subject of several production sharing contracts awarded by Kenya to various international oil companies, including Total and Eni. In separate letters to these companies, Somalia claims that part of the territory granted by Kenya falls within its exclusive economic zone, that the activities of oil companies in the region are illegal, and meant to impose daily fines on them for violating their sovereignty. Kenya and Somalia have negotiated a settlement of the dispute, but the two states have not reached an agreement yet. Somalia proposed the process before the ICJ. According to Somalia in its memorial, during the negotiations held in 2014, the two sides put forward positions that were so contradictory that no agreement was reached. This was more complicated by the fact that the meetings held on August 25 and 26, 2014, at the request of Kenya, did not take place because the Kenyans did not attend the meetings or provide an explanation to Somalia of their absence. Both Kenya and Somalia are parties to the 1982 United Nations Convention on the Law of the Sea (UNCLOS), having ratified in July and March 1989, respectively. Under Article 83(1) of this Convention, they are obliged to delimit their maritime boundaries by the agreement under international law. To reach a fair solution. Article 83 (1) does not specify the method of delimitation. However, the State seems to prefer the use of the same distance delimitation method. The ICJ itself has developed a three-stage delimitation methodology which is essentially the same distance. When using this methodology, the Court begins by drawing the same provisional line. Then the Court asked if any relevant circumstances were justifying this temporary shift or adjustment of the equidistant line. ${ }^{1}$ Finally, it performs a disproportionality test by checking that the area associated with a State under the first two stages is not proportional to the length of its coast. Although the methodology is standard and straightforward, its application is not without controversy. This methodology, according to Somalia, must be applied in dispute resolution. According to the Somalia memorial, no relevant circumstances justify a temporary shift in the equidistant line.

It is difficult to know for sure Kenya's claim to the Indian Ocean.

1 I Made Andi Arsana, Batas Maritim Antarnegara: Sebuah Tinjauan Teknis dan Yuridis. Gadjah Mada University Press, Yogyakarta, 2007, page. 48. 
Although Kenya has submitted its counter-memorial to the Court, and this has not been announced by the ICJ. The delay in filing the counter-memorial was due to Kenya's initial objection to the Court's jurisdiction, which resulted in suspending merit-based proceedings until these objections were resolved. Nonetheless, the document attached to the Somali warning detailing the negotiations between the parties indicates that Kenya does not want its boundaries to be defined using the equidistant method (referred to as the median line by Kenyans in these documents). Kenya, on the other hand, argues that UNCLOS does not regulate the use of the median line in the delimitation of the Exclusive Economic Zone (EEZ) or the continental shelf and that both States are free to choose a delimitation methodology that guarantees a fair solution. For Kenya, a fair solution means a proportionate division of the relevant maritime area based on the ratio of the "relevant shore length". ${ }^{2}$ They assert that the methodology for achieving this just solution is a line drawn along parallel latitudes. Kenya refers to two situations where latitudinal boundaries are drawn to correct for inequalities that would occur if a strict median line were drawn, this is called 'regional country practice'. Support for this position can be found in the official press statement made by the Office of the Attorney General and the Ministry of Justice of Kenya shortly after the counter-memorial filing on December 18, 2017. In that statement, Kenya confirmed that a line was drawn together.

The parallel latitude has existed as the boundary between Kenya and Somalia since 1979, and this has been recognized by Somalia until 2014. This shows that Kenya believes no boundary is actually drawn because it already exists. If the boundary line were drawn as Somalia requested, some of the territories that Kenya had given to certain international oil companies would belong to Somalia. In 2009, Kenya and Somalia signed a Memorandum of Understanding (MoU) giving prior approval to the Continental Shelf Boundary Commission to consider their application at the outer limits of their continental shelf beyond 200 nautical miles. While the agreement stated that they would not object to each other's submissions, they nevertheless agreed that the recommendations made by CLCS should be without prejudice to the boundaries of the continental shelf, including areas beyond 200 nautical miles. As stated in the MoU, it is necessary to enter into an agreement to fulfill the requirements of Article 4 Annex II of UNCLOS, which requires States Parties to UNCLOS to submit preliminary information about the outer boundaries of their continental shelf to CLCS within 10 years from the date the Convention enters into force for a particular State. Despite this agreement, after Kenya submitted its submission to the CLCS in 2009, Somalia objected to its consideration by the CLCS. Subject to paragraph 5(a), Annex I, CLCS Rules of Procedure, CLCS will not consider any submissions made by States when the area is the subject of submissions in dispute unless the parties to the dispute give prior consent. In any case, any consideration of surrender shall not prejudice the boundaries of the continental shelf between the parties to the dispute. Somalia, in October 2009, rejected the

2 Merilin L. I. Thomas, (2013). "Tinjauan Yuridis Penyelesaian Sengketa tentang Penetapan Batas Wilayah Laut Negara", Jurnal Lex et Societatis, 2(1): 162-164. 
MoU on the grounds that it had been rejected by Somalia's Transitional Federal Parliament and requested that the MoU be treated as 'nonactionable'. Although Somalia later withdrew its objections in consideration of Kenya's submission by the CLCS despite its stance that the MoU was null and void, in 2014, it instituted proceedings at the ICJ praying to the Court to determine the boundary between Somalia and Kenya in India. The sea passes through a line delimiting the territorial sea, the exclusive economic zone, and the continental shelf, including that part of the continental shelf beyond 200 nautical miles from the coast. The case has not yet been heard due to initial objections raised by Kenya. ${ }^{3}$

There was actually a few studies on the case of Kenya and Somalia, but most of studies focus on the analysis of the Judgment on Preliminary Objections as conducted by Xiaohui $\mathrm{Wu}$ in $2018^{4}$ as well as Francisco Lertora Pinto in $2017 . .^{5}$ While in this, the author elaborate the whole process of the case and analysed it through the perspective of International Law on Maritime Territorial Dispute.

\section{B. RESEARCH METHODS}

The research was conducted through a normative juridical approach pursuant to maritime law issues specifically the case between Kenya and Somalia under international law. The normative juridical approach was carried out by examining the theories, principles of law, and regulations. Furthermore, the research also used statutory, and case approaches. The data was obtained through books, legal journals, newspapers, and others. ${ }^{6}$ Furthermore, the legal materials were analyzed and grouped into categories according to the discussion, interpreted and connected with concepts relevant to the focus of the problem, described qualitatively using deductive-inductive methods to find answers to problems.

\section{THE DECISION OF THE INTERNATIONAL COURT OF JUSTICE (ICJ) ON MARITIME DISPUTES BETWEEN SOMALIA AND KENYA}

Somalia began litigation against Kenya at the International Court of Justice over the disputed Exclusive Economic Zone covering some 42,000 squares kilometres. Court Statutes, otherwise known as "optional clause declaration". In response, Kenya pointed to the reservation made under the article, which frees the Court to adjudicate the dispute, in which case the disputing parties have agreed to use some method for dispute resolution.

Kenya raised two independent objections to the Court's jurisdiction:

3 Fayokemi Olorundami, The Kenya/Somali Maritime Boundary Delimitation Dispute, University of Greenwich, UK: Springer, London, 2018, page.173-176.

4 Xiaohui Wu, Case Note: Maritime Delimitation in the Indian Ocean (Somalia v. Kenya), Judgment on Preliminary Objections, Chinese Journal of International Law, Volume 17, Issue 3, 2018, page 841-860

5 Francisco Lertora Pinto, The Application of the Rules on Interpretation of Treaties in the light of the Judgment on Preliminary Objections in the case between Somalia v. Kenya, Revista Tribuna Internacional, Volume 6, No 12, 2017

6 Soerjono Soekanto dan Sri Mamuji, Penelitian Hukum Normatif Suatu Tinjauan Singkat, Raja Grafindo Pustaka, Jakarta, 2006, page. 13. 
first, it demonstrated that the Memorandum of Understanding (MoU) signed between the parties to the dispute constituted an agreement to use some other method of settlement. Second, Kenya argues that the United Nations Convention on the Law of the Sea (UNCLOS), to which both States are parties, contains a dispute resolution mechanism which is also an agreement to use some other method.

In 2009, to reconcile the dispute between Somalia and Kenya, the two countries signed an MoU, which agreed on maritime territorial disputes between the two countries. In 2014, Somalia reported Kenya to the ICJ for unlawful operations on its territory. At that time, Kenya filed an initial objection to the ICJ's jurisdiction, but the application was rejected. Kenya claims that Somalia has auctioned off oil located in the disputed territory. Kenya also demands that Mogadishu refute findings presented at the London conference that the dispute falls within its jurisdiction. ${ }^{7}$ Against the first objection, the Court believes that it must first be ascertained the legal status of the MoU before analysing its contents. The MoU was signed by Kenya's Minister of Foreign Affairs and Somalia's Minister of National Planning and International Cooperation on April 7, 2009, before being registered by the UN Secretariat on June 11, 2009, at the request of Kenya. Although recognizing the MoU at the beginning, the Somalia authorities later denied the validity of the instrument.

Despite persistent protests against the MoU, Somalia further argues that the MoU is not ratified by Parliament, and allowing the Minister to sign a binding bilateral agreement is 'unusual for Somalia'. However, this debate was rejected by the Court. First, the Court appears to admit the Somalia protest unacceptable on the grounds of violation or consent. Second, since the MoU itself states that it will enter into force upon signature, ratification is not required. Finally, the Court observed that under customary international law, Somalia should not seek to revoke international legal obligations under internal law. Legal provisions on competence to conclude agreements; there is no reason to assume that Kenyans know that the Minister's signature may not be sufficient. ${ }^{8}$

After making the MoU an agreement legally binding on the parties, the Court ruled that this would be an agreement for several other dispute resolution methods. If so, then according to Kenya's reservation of the Court's jurisdiction, the Court has no jurisdiction. The point lies in paragraph 6 of the MoU, which reads: The determination of maritime boundaries in the disputed area will be agreed upon between the two countries based on international law after the Commission (On the Limits of the Continental Shelf, hereinafter CLCS) makes its recommendations to the two countries regarding the determination of the boundaries of the shelf continent beyond 200 nautical miles. Since this dispute has long been unresolved, the maritime dispute between Somalia and Kenya under the litigation of the International

7 Doreen Muyonga, Media, Confict, and Peacebuilding in Africa, Oxon, Abingdon, page. 8.

8 Abdiaziz Hussein Hassan, Nasrin Lubna, The Law of Maritime Delimitation and the ICJ's Judgement in Somalia V. Kenya, Faculty of Law Somali National University, Mogadishu, Somalia, Department of Law, North Bengal International University, Rajshahi, Bangladesh, 2019, page. 2-3. 
Court of Justice seeks to reconcile the two countries. With reference to cases from across Africa, as a vehicle for resource disputes, especially transboundary fisheries, which have received little attention. The resolution of the Kenya-Somalia maritime dispute as cooperation in fisheries management will have a wider impact on diplomatic relations. ${ }^{9}$

It is difficult to process disputes between the two countries since politics may determine the resolution of disputes. Decisions must also be balanced against the broader political and economic objectives referenced in documents such as the 2050 Africa's Integrated Maritime Strategy (AIMS) and the maritime strategies of the five African Regional Economic Communities (RECs). It is not clear how integration can proceed without clarifying the location of the border and resolving disputes. ${ }^{10}$

There is also a settlement method through negotiations, namely by way of dispute resolution, which is the most important and widely adopted and effective in resolving international disputes. State practice shows that the initial resolution of disputes is through negotiation. In negotiations, countries can usually send representatives of the foreign minister, ambassadors, or specially appointed representatives of the disputing countries to negotiate within a diplomatic framework. ${ }^{11}$ However, this negotiation method is considered a failure, not enough to resolve the dispute between Kenya and Somalia. So that dispute resolution through coercion or violence can occur due to the seizure of natural resources in the marine area. ${ }^{12}$

It is necessary to distinguish between delineation and delimitation of the continental shelf beyond 200 nautical miles: although the two acts are essentially States drawing lines on their territory, the subject matter and procedures of each differ. Delineation involves drawing a line between the coastal State (the part of the High Seas defined as the "common heritage of mankind" by Article 137 of UNCLOS), and delimitation involves establishing a line between two coastal States. ${ }^{13}$

In order to prevent the coastal State from overclaiming the deep continental shelf, Art. 76 UNCLOS requires signatories to make submissions to the CLCS, which will make recommendations to coastal States. On the other hand, delimitation does not have such a requirement: communication with neighbouring countries is sufficient. While the two acts are distinct, to ensure that their actions do not affect matters relating to delimitation, according to its rules of procedure, CLCS will not consider filing a delineation if there is an

9 Nelly Isigi Kadagi,Ifesinachi Okafor-Yarwood,Sarah Glaser,Zachary Lien, Joint Management of Shared Resources as an Alternative Approach for Addressing Maritime Boundary Disputes: The Kenya-Somalia Maritime Boundary Disputes, Journal of the Indian Ocean Region, 2020, page1-23.

10 Timothy Walker, Why Africa must Resolve its Maritime Boundary Disputes, Institute for Security Studies (ISS), 2015, page. 5.

11 Ummi Yusnita, Penyelesaian Sengketa Batas Laut antara Indonesia dan Malayasia dalam Perspektif Hukum Internasional, Binamulia Hukum, Vol.7 No.1, page.96-106.

12 Andreas Pramudianto, Peradilan Internasional dan Diplomasi dalam Sengketa Lingkungan Hidup Maritim, Jurnal Hukum Lingkungan Indonesia, Vol 4 No.1, 2017, page.111-137.

13 Saru Arifin, Hukum Perbatasan Darat Antarnegara, Sinar Grafika, Jakarta, 2014, page. 79. 
ongoing dispute regarding the 'unlimited delimitation of a permit of all the countries concerned.

Kenya is trying to establish the temporal relation that delimitation must occur after delineation. Then argued that since paragraph 6 of the MoU makes a firm statement that the issue of delimitation will be agreed upon between the two coastal states only after the CLCS has made its recommendation on delineation, the Court's decision on delimitation can only be taken after that. The Court rejected this argument on the grounds that according to the words of the title and the first five paragraphs of the MoU, the parties intended to keep the delineation and delimitation processes distinct.

In this regard, the Court makes an important observation that the purpose of the MoU is not to establish alternative dispute resolution methods but rather to give the parties consent to allow CLCS to continue reviewing submissions despite disputes over delimitation. The Court's interpretation of the objectives and intentions of the parties in the MoU is basically threefold. First, analyse the title words as well as the first five paragraphs before finding that they contain no commitment or obligation whatsoever as to how the dispute should be resolved. Second, with respect to paragraph 6, which contains the word must, the Court uses the method of interpretation according to customary international law codified by Art. 31(3)(c) the Vienna Convention on the Law of Treaties (VCLT), which makes it possible to take into account the relevant rules of international law applicable in the relationship between the parties. Since Kenya and Somalia are parties to UNCLOS, the Court observes that there is a degree of similarity between paragraph 6 and Art. 83 UNCLOS (the latter reads 'the delimitation of the continental shelf between States with opposite or adjacent coasts must be carried out by agreement under international law, as referred to in Article 38 of the ICJ Statute. In paragraph 6 of the MoU under Article 83 of UNCLOS, the Court is of the opinion that because the latter simply 'requires that negotiations be conducted in good faith' and does not specify a method for the resolution of any dispute, neither does the former.

In the Court's view, this interpretation is further supported by the further practice Article 31(3)(b) VCLT of the parties involved in the negotiations in 2014, even before CLCS issued any recommendations regarding delineation. If Kenya truly believed that delimitation could only occur after delineation, according to the Court, it would not initiate such negotiations. Finally, the Court judged the MoU travaux preparatoires: interestingly, the text of the MoU was not drafted by either party but by the Norwegian Ambassador as part of Norway's assistance to the legal development of African countries. The Court's argument was that if paragraph 6 had the dispute resolution function claimed by Kenya, this would have been highlighted by the Norwegian Ambassador. However, since the Ambassador's previous talk on the MoU contained nothing about paragraph 6, the Court concluded that the MoU was insignificant.

With respect to the second objection, Kenya argues that according to Art. 287 paragraph 3 of UNCLOS, States Parties that do not choose their preferred dispute resolution mechanism will be deemed to have 'accepted 
arbitration in accordance with Annex VII' of UNCLOS. As neither party makes the choice of the dispute resolution mechanism, Kenya is of the opinion that the Arbitration Appendix VII should constitute an agreement of the parties to seek recourse to some other method, which would fall under Kenya's reservation to the jurisdiction of the Court.

On the other hand, Somalia relies on Art. 282 UNCLOS, which provides that if a signatory has agreed, by general, regional, or bilateral agreement, that the dispute, at the request of one of the parties to the dispute, be submitted to a procedure requiring a binding decision, and the applicable procedure is not from Appendix VII Arbitration. Even in the case of a reservation like Kenya, it is still a general agreement to resolve the dispute. Otherwise, it would preclude the jurisdiction of the UNCLOS tribunal. Kenya's answer to this is that with reservation to the jurisdiction of the Courts mentioned above, there is no general agreement to settle disputes in Courts and Articles. 282, therefore, does not apply. The Court's solution to this problem lies in its observation of the structure of UNCLOS and its interpretation of UNCLOS travaux preparatoires. ${ }^{14}$ Regarding the structure of UNCLOS, the Court reaffirms that according to Art. 286, Art. 287 if no settlement is reached with the help of the articles, including Art. 282. In other words, Appendix VII Arbitration and other mechanisms under Art. 287 plays only a residual role compared to the general mechanism set out in Art. 282. This cannot resolve the dispute because it is precisely Kenya's opinion that no settlement can be reached under Art. 282 with its reservation: Accordingly, the Court considers it necessary to investigate travaux preparatoires.

Despite the prevalence of objections to the Court's jurisdiction as in Kenya, there is no indication in the travaux preparatoires to exclude the Court's jurisdiction. Therefore, the reasoning here is very similar to that used above in the travaux preparatoires MoU: if there is an intention to exclude the jurisdiction of the Court, there will be some dispute about it. The Court also stated that in Art. 282 to make the article as broad as possible in favour of the Court's jurisdiction, potentially covering less specific reservations (such as those in Kenya).

The Court, therefore, has jurisdiction because of both the MoU and Art. 282 UNCLOS is an alternative dispute resolution mechanism that falls under Kenya's reservation to the jurisdiction of the Court. As a final note, the Court added that taking jurisdiction has the benefit of avoiding negative jurisdictional conflicts.

In international law itself, Kenya-Somalia maritime disputes can be resolved by the following methods:

\section{Peaceful Dispute Resolution}

Regarding the settlement of international disputes, Article 2 paragraph (3) of the 1945 United Nations Charter stipulates that "All Members shall settle their international disputes by peaceful means in such manner that international peace and security, and justice are not

14 Kai-chieh Cha, The ICJ's Judgement in Somalia v. Kenya and its Implications for the Law of the Sea, Utrecht Journal of International and European Law, Vol.34 No.2, 2018, page. 195. 
endangered." This article is the basis for peaceful dispute resolution. Based on the provisions of the article, all members of the United Nations must resolve their international disputes by peaceful means in such a way that international peace and security, and justice are not threatened. Although this obligation is addressed primarily to the Member States of the organization, there is no doubt that dispute resolution must be carried out peacefully is one of the primary obligations in international law that must be considered by all countries. Some of the principles that are known in the peaceful settlement of disputes, namely:

a. The principle of good faith (bona fides)

Based on this principle, the parties are required to have good faith in resolving the dispute. In dispute resolution, this principle can be seen in the stages: 1 . It is required to prevent disputes from arising; and 2. When the parties resolve their dispute by internationally recognized means of settlement such as mediation, negotiation, conciliation, arbitration, court, or other means chosen by the parties, an example of setting the principle of good faith can be seen in Section 1 Paragraph 1 Manila Declaration, Article 13 Treaty of Amity and Cooperation in Southeast Asia (Bali Concord 1976), Section 1 Paragraph 5 Manila Declaration. The principle of good faith is also a basic principle related to the creation and execution of legal obligations in the realm of public international law. As one example, the principle of good faith is contained in Article 26 of the Vienna Convention on the Law of Treaties. ${ }^{15}$

b. The principle of prohibiting the use of violence in dispute resolution

With this principle, the disputing parties in international disputes are prohibited from resolving their disputes through violence or by using weapons. An example of setting this principle can be found in Article 13 of the Bali Concord, 4th of the Manila Declaration. The principle of freedom to choose the methods of dispute resolution. According to this principle, the parties to a dispute have complete freedom to choose the means of resolving international disputes. As stipulated in Article 2 paragraph (3) jo. Article 33 (1) of the United Nations Charter in which the settlement of disputes is basically carried out by peaceful means in such a way that regarding the type of peaceful settlement, there is an open space for the parties to choose, whether it is determined by the UN Charter or other peaceful means agreed by the parties dispute.

c. The principle of freedom of choice of law applied in the subject matter of the dispute

If the parties' international disputes are resolved through the judiciary, the parties are given the freedom to choose which law is applied to the subject matter of the dispute. In this regard, Article 38 (2) of the Statute of the International Court of Justice basically

15 Sefriani, Peran Hukum Internasional dalam Hubungan Internasional Kontemporer, Raja Grafindo Persada, Jakarta, page. 84 
stipulates that "This provision shall not prejudice the power of the Court to decide a case ex aequo et bono, if the parties agree hereon". This means the parties also have the freedom in terms of choosing propriety or feasibility.

d. The principle of agreement of the disputing parties (consensus)

The principle of consensus between the disputing parties is the basis for the implementation of the principle of freedom to choose the method of dispute resolution and to choose the law to be applied in the subject matter of the dispute. Basically, the parties must collectively agree in order to make their choice.

e. The principle of exhaustion of local remedies

Based on this principle, before the party who feels aggrieved in the dispute submits its dispute at the international level, the national court is given the opportunity to provide a remedy to it. After knowing the provisions of Article 2 paragraph (3) of the UN Charter and several principles in international dispute resolution, Furthermore, referring to the provisions of Article 33 paragraph (1) of the UN Charter, it is known that "The parties to any dispute, the continuance of which is likely to endanger the maintenance of international peace and security, shall, first of all, seek a solution by negotiation, inquiry, mediation, conciliation, arbitration, judicial settlement, resort to regional agencies or arrangements, or other peaceful means of their own choice". So that the methods of peaceful dispute resolution that must first be taken by the parties in any dispute whose continuation tends to endanger the maintenance of international peace and security as regulated according to Article 33 paragraph (1) of the United Nations Charter are through negotiation, fact-finding, mediation, conciliation, arbitration, settlement through the judiciary, brought to a regional/regional board or management or based on other peaceful options of the parties.

\section{Negotiation}

Negotiation is the simplest method and is therefore widely used in the international dispute resolution process. In general, negotiations consist of a number of discussions among interested parties to find common ground on their differences of opinion or at least understand each other's different views expressed. The International Court of Justice, in the case of German External Debts, asserted that the obligation to reach consensus is not always implied in negotiating agreements, "it does imply that serious efforts to move upwards must be made." In the negotiation process, there is no third-party participation in the dispute resolution process. Negotiations can be carried out bilaterally, multilaterally, formally, or informally because there is no specific procedure. However, it is necessary to distinguish between the negotiation procedure used when the dispute has not yet arisen, which is referred to as consultation with the negotiation used after the dispute is born, which is a negotiation of the dispute resolution process in the sense of negotiation. Negotiation is considered the most important way because every day, many disputes can be resolved 
without going through public attention. Thus, it can be said as one of the advantages of negotiation. Meanwhile, some of the weaknesses of negotiations are: if the position of the parties to the dispute is not balanced, the potential for creating a strong party will suppress the weak party; often takes a long time, and if one of the parties is too adamant about their position then the negotiation process becomes unproductive. ${ }^{16}$

\section{Fact-Finding (inquiry)}

One of the international disputes can occur because of the conflicting views of the disputing parties to a fact that often determines their rights and obligations. Therefore, fact-finding is basically a peaceful dispute resolution method by establishing an official factfinding/investigation commission carried out by a reputable observer with the aim of ascertaining the facts in dispute. Basically, this method can be chosen to settle an international dispute if the parties to the dispute agree to use this method. Based on the above understanding, it is known that the role of third parties is involved in the fact-finding process. The role of a third party, which is less formal in nature - thus not a court, is involved in this process because generally, the parties to a dispute take this method after they themselves are unable to produce a settlement, for example, through negotiation. Fact-finding can be carried out by a commission to which selected harvesters, organizations, or individuals can provide their expert opinion.

\section{Mediation}

Mediation is an extension and elaboration of the negotiation process that involves the intervention of an acceptable, impartial and neutral third party who has no decision-making authority to help the competing parties voluntarily reach their own mutually acceptable settlement. Referring to the definition of mediation, it includes the involvement of third parties in the dispute resolution process. This third party is referred to as a mediator. The mediator can be a state, an international organization, for example, the United Nations, or an individual such as a lawyer, scientist, and politician. Of course, the mediators must be acceptable to the parties to the dispute, impartial and neutral. The role of the mediator in mediation is active in the sense that he is tasked with reconciling the disputing parties, has certain authority to lead the negotiations and distributes proposals to the disputing parties. Similar to fact-finding, mediation also requires prior approval of the disputing parties to use this method as a dispute resolution. ${ }^{17}$

16 W. Poeggel and E. Oeser, Methods of Diplomatic Settlement, dalam Mohammed Bedjaoui (ed.), International Law: Achievements and Prospects, Martinus Nijhoff and UNESCO: Dordrescht, 1991, page. 514.

17 Sri Setianingsih Suwardi, Penyelesaian Sengketa Internasional, UI Press, Jakarta, 2006, page. 18. 


\section{Conciliation}

Conciliation has the meaning of a dispute resolution process by referring it to a commission of persons whose job it is to explain the facts and (usually after hearing the parties and trying to bring them to an agreement) to produce a report which contains proposals for a settlement, but which is not binding. Based on this definition, it is known that this method uses the role of a third party known as the Conciliation Commission. This commission can be institutionalized or temporary (ad hoc). Basically, dispute resolution by conciliation is a more structured and quasi-judicial way than mediation. If the disputing parties choose to use conciliation, then they will first describe the dispute in written form, which is then submitted to the conciliation commission. After that, in the second stage, the parties to the dispute (can be represented by their proxies) are asked to attend the hearing stage. After the conciliation commission has obtained the required facts, it will provide its report to the disputing parties, which basically contains the proposal for the settlement of the dispute. As the definition of conciliation above, the proposal from a third party, namely the conciliation commission, is not for the parties. Therefore, this proposal is left to the disputing parties whether to be approved or not.

\section{Arbitration}

Arbitration means the appointment of a third party to act as an adjudicator (the party adjudicating) in a dispute and to decide its settlement. Arbitration differs from mediation and conciliation in that it does not promote the continuation of collective bargaining. This is because the role of third parties in an arbitration, referred to as arbitrators, is very active in terms of intervening in disputes and taking the role of decision-makers. The arbitrator is a third party who is fully elected based on the agreement of the parties, is an expert in the subject of the dispute, is neutral, does not have to be a legal expert. However, the reality is that in the composition of the arbitration board, at least there is still the role of legal experts, as well as neutral parties. The award issued in this arbitration is final and binding. ${ }^{18}$ If the parties make an agreement and agree to include a clause on dispute resolution through arbitration before the dispute is born, then this submission is called a clause compromissoire. Meanwhile, if the dispute has been born and will be resolved through arbitration, this submission is called a compromise. This method of settlement through arbitration can be done either through a settlement with an arbitrator in an institutionalized manner, in the sense that it has been previously established and has procedural law, for example, the Permanent Court of Arbitration (PCA), or with an (ad hoc) arbitration body, which means made by the parties temporarily and their duties end after a decision on a dispute is issued. Referring to the subject matter, arbitration can be divided into two

18 Priyatna Abdurrasyid, Arbitrase Dan Alternatif Penyelesaian Sengketa (APS) Suatu Pengantar, Fikahati Aneska, Jakarta, 2011, page. 61. 
major parts, namely: 1 . Non-commercial arbitration is often called public international arbitration. An example is PCA; and 2. Commercial arbitration is often referred to as civil. This commercial term, according to Huala Adolf, refers to trade, money traffic, commerce in general, so that it includes insurance, leasing, lending and borrowing, and so on. An example is The International Centre for the Settlement of Investment Dispute (ICSID). ICSID will be discussed further in settlement of trade disputes in the next sub-chapter.

\section{The Permanent Court of Arbitration (PCA)}

The PCA is the first global institution to adjudicate international disputes which were established with the Convention for the Pacific Settlement of International Disputes 1899, which was further revised by the Hague Convention for the Pacific Settlement of International Disputes 1907. PCA is located in the Peace Palace, the Hague, Netherlands. Although PCA's headquarters are in Hague, arbitrations held under its auspices may be conducted at another location agreed by the parties. The PCA resolves not only international disputes through arbitration but also by other peaceful means. For example, fact-finding, conciliation, mediation, or goodwill. The PCA has 121 contracting parties that have agreed to one or both of the PCA's founding conventions, as noted above. The PCA has an organizational structure consisting of three parts, namely: the Administrative Council, which oversees its policies and budgets, a panel of potential independent arbitrators known as the Members of the Court, and its Secretariat, known as the International Bureau headed by the General Secretary. The basic rules for conducting PCA arbitration are regulated in the Convention for the Pacific Settlement of International Disputes 1899 and the Hague Convention for the Pacific Settlement of International Disputes 1907 (the 1899/1907 Conventions). However, from 1992 to the present, the PCA has developed a series of optional rules to govern the various types of arbitration that may go to the PCA. These optional rules are based on the UNCITRAL Arbitration Rules. The PCA's original jurisdiction under the 1899/1907 Conventions was limited to disputes between countries. The exercise of this jurisdiction is dependent on a generally written agreement between the parties referring the dispute to PCA arbitration which can be made on an ad hoc basis or through a compromising clause found in a valid treaty. Subsequently, various optional regulations broaden the scope of jurisdiction of the PCA, whereby the disputing parties can now include states, state entities, intergovernmental organizations, and non-state entities/private parties. Regarding the ratione materiae PCA, it is essentially unlimited. However, in each case, the scope of the arbitral tribunal's jurisdiction is determined by the wording of the applicable arbitration clause (compromise).

\section{Settlement through the Court (Judicial Settlement)}

The settlement of international disputes through the judiciary is usually carried out when other means are unsuccessful. Settlement 
through this trial can be divided into two, namely: (1) Permanent international courts, for example, Permanent Court of International of Justice (PCIJ), International Court of Justice (International Court of Justice), International Tribunal for the Law of the Sea, International Criminal Court (International Criminal Court); and (2) $A d$ hoc international courts, for example, the International Court Tribunal for Rwanda and the International Court Tribunal for Yugoslavia. Below will be briefly explained about the International Court of Justice and the International Criminal Court.

\section{International Court of Justice (ICJ)}

Arrangements regarding the ICJ can be found in the 1945 Statute of the International Court of Justice. Article 1 of the Statute of the International Court of Justice provides that the International Court of Justice is established by the United Nations Charter as the principal judicial organ of the United Nations. Only the state can be a party to bring a dispute to this court. Countries that have access to the Court are member states of the United Nations or non-member countries of the United Nations that are parties to the Statute of the International Court of Justice on condition that they obtain a recommendation from the Security Council and are approved by the General Assembly. There are 15 judges on the Court, each with a different nationality, who are selected by the General Assembly and the Security Council from a list of individuals nominated by national groups at the PCA. The jurisdiction of the International Court of Justice consists of: (1) The subject matter of the dispute it submits is called contentious jurisdiction, and (2) Jurisdiction providing legal advice/advisory opinion is referred to as noncontentious jurisdiction. One of the example cases brought before the Court was the North Sea Continental Shelf. ${ }^{19}$

\section{CONCLUSION}

With refers to Art. 287 paragraph 3 of UNCLOS, As neither party makes the choice of a dispute resolution mechanism, Kenya is of the opinion that the Arbitration of Appendix VII should constitute an agreement of the parties to seek recourse to some other method, which would fall under Kenya's reservation to the jurisdiction of the Court. On the other hand, Somalia relies on Art. 282 UNCLOS, which provides that if a signatory 'has agreed, by general, regional or bilateral agreement or otherwise, that the dispute, at the request of one of the parties to the dispute, be submitted to a procedure requiring a binding decision, that procedure shall apply' is not Appendix VII Arbitration. It is claimed that the acceptance of the parties to the jurisdiction of the Court, even in the case of a reservation such as Kenya,

19 I Made Pasek Diantha, Ida Bagus Wyasa Putra, Putu Tuny Cakabawa Landra, I Dewa Gede Palguna, I Gede Pasek Eka Wisanjaya, Made Maharta Yasa, A.A. Sri Utari, A.A. Gede Duwira Hadi Santosa, I Made Budi Arsika, Made Suksma Prijandhini Devi Salain, I Gede Putra Ariana, I Gusti Ngurah Parikesit Widiatedja, Cok Istri Diah Widyantari Pradnya Dewi, Putu Aras Samsithawrati, Hukum Internasional, Fakultas Hukum Universitas Udayana, Bali, 2017, page. 189-201 
is still a general agreement to resolve the dispute otherwise and would thus preclude the jurisdiction of the UNCLOS tribunal. Kenya's answer to this is that with reservation to the jurisdiction of the aforementioned Courts, there is no general agreement to settle disputes in the Courts and Art. 282, therefore, does not apply. The Court's solution to this lies in its observation of the structure of UNCLOS and its interpretation of UNCLOS travaux preparatoires. Regarding the structure of UNCLOS, the Court reaffirms that according to Art. 286, Art. 287 is only important if 'no settlement is reached with the help of the articles, including Art. 282. In other words, Appendix VII Arbitration and other mechanisms under Art. 287 plays only a residual role compared to the general mechanism set out in Art. 282. This alone, however, does not solve the question because it is precisely Kenya's opinion that 'no settlement can be reached' under Art. 282 with its reservation: The Court thus found it necessary to look into the travaux preparatoires. The Court, therefore, finds itself to have jurisdiction due to neither the MoU nor Art. 282 of UNCLOS is an alternative dispute resolution mechanism that falls under Kenya's reservation to the jurisdiction of the Court. As a final note, the Court adds that taking jurisdiction has the benefit of avoiding negative jurisdictional conflicts.

\section{Books:}

\section{BIBLIOGRAPHY}

Arifin, Saru, 2014, Hukum Perbatasan Darat Antarnegara, Sinar Grafika, Jakarta;

Arsana, I Made Andi, 2007, Batas Maritim Antarnegara: Sebuah Tinjauan Teknis dan Yuridis, Gadjah Mada University Press, Yogyakarta;

Diantha I Made Pasek, Putra Ida Bagus Wyasa, Landra Putu, Palguna I Dewa, Wisanjaya I Gede, Yasa Made, Utari A.A, Santosa A.A, Arsika I Made, Salain Made, Ariana I Gede, Widiatedja I Gusti, Dewi Cok, Samsithawrati Putu, 2017, Hukum Internasional, Fakultas Hukum Universitas Udayana, Bali;

Hassan, Huessein Abdiaziz, Nasrin Lubna, 2019, The Law of Maritime Delimitation and the ICJ's Judgement in Somalia V. Kenya. Faculty of Law Somali National University, Mogadishu, Somalia, Department of Law, North Bengal International University, Rajshahi, Bangladesh;

Muyonga Doreen, 2021, Media, Confict, and Peacebuilding in Africa, Oxon, Abingdon;

Olorundami, Fayokemi, 2018, The Kenya/Somali Maritime Boundary Delimitation Dispute, University of Greenwich, Springer, London, UK;

Priyatna Abdurrasyid, 2011, Arbitrase Dan Alternatif Penyelesaian Sengketa (APS) Suatu Pengantar, Fikahati Aneska, Jakarta;

Sefriani, 2016, Peran Hukum Internasional dalam Hubungan Internasional Kontemporer, Raja Grafindo Persada, Jakarta;

Soerjono Soekanto dan Sri Mamuji, 2006, Penelitian Hukum Normatif Suatu Tinjauan Singkat, Raja Grafindo Pustaka, Jakarta; 
Suwardi Sri Setianingsih, 2006, Penyelesaian Sengketa Internasional, UI Press, Jakarta;

W. Poeggel and E. Oeser, 1991, Methods of Diplomatic Settlement, dalam Mohammed Bedjaoui (ed.), International Law: Achievements and Prospects, Martinus Nijhoff and UNESCO, Dordrescht;

Walker Timothy. (2015). Why Africa Must Resolve its Maritime Boundary Disputes, Institute for Security Studies (ISS).

\section{Journals:}

Francisco Lertora Pinto, The Application of the Rules on Interpretation of Treaties in the light of the Judgment on Preliminary Objections in the case between Somalia v. Kenya, Revista Tribuna Internacional, Vol.6 No.12, 2017;

Kadagi, Isigi Nelly, Ifesinachi Okafor-Yarwood,Sarah Glaser,Zachary Lien, Joint Management of Shared Resources as an Alternative Approach for Addressing Maritime Boundary Disputes: The Kenya-Somalia Maritime Boundary Disputes, Journal of the Indian Ocean Region, Vol.16 No.3, 2020;

Kai-chieh Chan, The ICJ's Judgement in Somalia v. Kenya and its Implications for the Law of the Sea, Utrecht Journal of International and European Law, Vol.34 No.2, 2018;

Thomas Merilin L. I, Tinjauan Yuridis Penyelesaian Sengketa tentang Penetapan Batas Wilayah Laut Negara, Jurnal Lex et Societatis, Volume I No. 2, 2013

Xiaohui $\mathrm{Wu}$, Case Note: Maritime Delimitation in the Indian Ocean (Somalia v. Kenya), Judgment on Preliminary Objections", Chinese Journal of International Law, Vol.17 No.3,2018;

Yusnita Ummi, Penyelesaian Sengketa Batas Laut antara Indonesia dan Malayasia dalam Perspektif Hukum Internasional, Binamulia Hukum, Vol.7 No.1, 2018 